\title{
Sustained Nutrient Management Practice for Pulse Production: A Review
}

\author{
Vinayak Hosamani $^{1 *}$, B. M. Chittapur ${ }^{1}$, Venkatesh Hosamani ${ }^{2}$ and Rajanand Hiremath ${ }^{3}$ \\ ${ }^{1}$ University of Agricultural Sciences, Raichur, Karnataka, India \\ ${ }^{2}$ College of Horticulture, Munirabad-Koppal, Karnataka, India \\ ${ }^{3}$ College of Horticulture, Kerala Agriculture University, Thrissur, Kerala, India \\ *Corresponding author
}

\begin{tabular}{|c|c|}
\hline & A B S T R A C T \\
\hline & \multirow{6}{*}{$\begin{array}{l}\text { The low yield of pulses is mainly attributed to their cultivation on poor soils with } \\
\text { inadequate and imbalanced nutrient application without the application of organic } \\
\text { manures and micronutrients like boron, zinc and iron. Since the poor soils are low in } \\
\text { organic matter content, use of organic manures plays a vital role in improving soil } \\
\text { physical condition, provides vital plant nutrients and maintains long term productivity } \\
\text { of the soil. Boron helps in carbohydrate transport. It is necessary for the germination } \\
\text { of pollen, formation of flowers and fruits and for the absorption of cations. The use of } \\
\text { inorganic fertilizers along with bulky organic manures was found more advantageous } \\
\text { in enhancing crop yields. According to several studies conducted in different crops by } \\
\text { scientists over the world revealed that, retention of flowers is possible through foliar } \\
\text { application of growth regulators as well as macronutrients during flower initiation and } \\
\text { pod development stages along with soil application of micronutrients hence, the } \\
\text { review. }\end{array}$} \\
\hline & \\
\hline $\begin{array}{l}\text { Pigeonpea, RDF, } \\
\text { NPK. }\end{array}$ & \\
\hline Article Info & \\
\hline $\begin{array}{l}\text { Accepted: } \\
\text { 26 September } 2017 \\
\text { Available Online: } \\
\text { 10 November } 2017\end{array}$ & \\
\hline & \\
\hline
\end{tabular}

\section{Introduction}

Pulses provide the vital protein and vitamins in an average Indian diet. They form a major source of dietary protein especially for vegetarians which form a major part of our population. The static production of pulses in India coupled with an exploding population has led to steep fall in the per capita availability of pulses from 70 gram per day in 1960-61 to less than 40 gram per day during present decade (Pushpa, 2007) as against FAO/WHO's recommendation of 80 gram per day (Asthana and Chaturvedi, 1999). The crisis of shortage of pulses has aggravated the problem of malnutrition. Thus, there is an urgent need to increase production of pulses to meet the requirement by manipulating production technologies appropriately. Very little work has been carried out regarding the response of pulses to soil application of micronutrients and foliar spray of macronutrients under protective irrigation. Hence, this attempt

\section{Effect of N, $P$ and $K$ on growth and yield}

Balanced fertilization i.e., appropriate quantity of nutrients in required proportions at right time, applied through right method increase the yield levels. In India several studies have been carried out on the field to 
identify the suitable nutrient management practices to increase the productivity of peagenpea. Sarkar et al., (1997) concluded that application of FYM @ $10 \mathrm{t} \mathrm{ha}^{-1}$ gave significantly higher $(16.7 \%)$ grain yield of pigeonpea over no FYM. P@ $90 \mathrm{~kg} \mathrm{P}_{2} \mathrm{O}_{5} \mathrm{ha}^{-1}$ resulted in 6.36 per cent higher yield than $\mathrm{P} @$ $45 \mathrm{~kg} \quad \mathrm{P}_{2} \mathrm{O}_{5} \quad \mathrm{ha}^{-1}$ similarly Pujari and Gaddankeri (1998) reported that application of farm yard manure @ $500 \mathrm{~kg} \mathrm{ha}^{-1}$ along with recommended inorganic fertilizers in the seed line resulted in 15 per cent higher grain yield of kharif pigeonpea compared to recommended inorganic fertilizers and FYM applied in traditional method. Ramachandra Reddy et al., (1998) reported that application of vermicompost @ 10t ha ${ }^{-1}$ and recommended dose of NPK (37.5:60:50kg $\mathrm{ha}^{-1}$ ) recorded maximum yield $\left(8828 \mathrm{~kg} \mathrm{ha}^{-1}\right)$, plant height, days to initial flowering, number of branches per plant, number of pods and seeds per pod of pea while, Babhulkar et al., (2000) studied the residual effect of long-term use of fertilizers alone and in combination with FYM on soil health and yield of soybean. The results indicated higher yield $\left(24.97 \mathrm{q} \mathrm{ha}^{-1}\right)$ with the application of FYM @ $7.5 \mathrm{t} \mathrm{ha}^{-1}$ along with half dose of recommended $\mathrm{N}$ and $\mathrm{P}$ registered 26.81 and 20.10 per cent increase over control and full dose of fertilizers respectively.

Similarly, Lokesha (2001) obtained higher grain yield of pigeonpea (18.92 $\left.\mathrm{q} \mathrm{ha}^{-1}\right)$ and higher net returns (Rs. 22,822 ha ${ }^{-1}$ ) by sowing after the receipt of normal rainfall with broadcasting of FYM and application of RDF. Rajkhowa et al., (2002) conducted experiment to study the effect of vermicompost with and without fertilizer on green gram and concluded that use of vermicompost @ 2.5t ha $^{-1}$ along with 50 per cent RDF was economically beneficial for realizing the higher productivity of green gram. Bhattarai et al., (2003) studied the effect of integrated nutrient management on yield attributes and economics of Pea (Pisum sativum) and concluded that application of poultry manure along with full dose of nutrients recorded the highest pods per plant (19.66), seeds per pod (6.35) and seed yield $\left(2 \mathrm{tha}^{-1}\right)$. This treatment also recorded the highest net returns (Rs 25,400 ha ${ }^{-1}$ ). Ajay Kumar and Rana (2007) conducted an experiment and concluded that application of soil mulch + farmyard manure @ $5 \mathrm{t} \mathrm{ha}^{-1}+$ kaolin @ 6\% spray was found the best moisture conservation practice by recording the maximum values of pigeonpea equivalent yield, nutrient uptake and water use efficiency. Application of $40 \mathrm{~kg} \mathrm{P}_{2} \mathrm{O}_{5} \mathrm{ha}^{-1}$ $+25 \mathrm{~kg} \mathrm{~S} \mathrm{ha}^{-1}$ +phosphate solubilizing bacteria (PSB) recorded the maximum values of pigeonpea-equivalent yield, nutrient uptake, water use efficiency and net returns. Pigeonpea crop manured with FYM at $5 \mathrm{t} \mathrm{ha}^{-1}$ significantly improved the growth parameters like plant height, number of branches per plant at harvest and number of root nodules at 30, 60 and 90 DAS and at harvest as well as yield attributes like number of pods per plant, grains per pod, grain weight per plant and test weight as compared to control (without FYM). Manuring the crop with FYM at 5 tha ${ }^{1}$ recorded 4.26 per cent higher grain yield and 12 per cent higher stover yield over no manuring (Patil and Padmani, 2007). Patil et al., (2008) studied the effect of integrated nutrient management for pigeonpea + pearl millet intercropping system under dry land conditions and revealed that maximum productivity and net returns, improvement in fertility status and chemical properties of soil could be possible from pigeonpeat pearl millet intercropping system with application of $50 \% \mathrm{RDF}$ of the respective crops on the basis of area. Proportion and use of $50 \%$ RDF + vermicompost @ 3 t/ha or FYM @ 5 t/ha + biofertilizers was found to be best proposition for INM system for the intercropping system. While, Arjun Sharma et al., (2010a) conducted experiment on integrated nutrient management in pigeonpea 
(Cajanus cajan L.) based intercropping systems under rainfed conditions and revealed that pigeonpea + green gram intercropping system recorded significantly higher pigeonpea seed yield $\left(13.75 \mathrm{q} \quad \mathrm{ha}^{-1}\right)$, pigeonpea equivalent yield (17.37 $\left.\mathrm{q} \mathrm{ha}^{-1}\right)$, gross returns (Rs. 31,273 $\mathrm{ha}^{-1}$ ), net returns (Rs. 22,546 $\mathrm{ha}^{-1}$ ) and $\mathrm{BC}$ ratio (3.59) over pigeonpea + pearl millet intercropping system (13.26 q ha ${ }^{-1}, 15.76 \mathrm{q} \mathrm{ha}^{-1}$, Rs. 28,365 ha ${ }^{-1}$, Rs. $19,838 \mathrm{ha}^{-1}$ and 3.34, respectively). Among the INM practices, application of 50 per cent RDF + Vermicompost @ $2.5 \mathrm{t} \mathrm{ha}^{-1}$ recorded significantly higher pigeonpea yield (15.72 $\left.\mathrm{q} \mathrm{ha}^{-1}\right)$, pigeonpea equivalent yield (19.36 q ha-1), gross returns (Rs.34,849 ha-1) and net returns (Rs. 24,506 ha-1) over other INM practices and it was found to be on par with application of phosphocompost @ $2.5 \mathrm{t}$ $\mathrm{ha}^{-1}+50 \%$ RDF.

Arjun Sharma et al., (2010b) revealed that application of $100 \%$ RDF along with FYM @ $5 \mathrm{tha}^{-1}+$ opening of shallow furrows between two rows recorded significantly higher seed yield (16.35 q ha-1), stalk yield (45.48 q ha-1), gross returns (Rs. 40,875 $\mathrm{ha}^{-1}$ ), net returns (Rs. 31,434 $\mathrm{ha}^{-1}$ ) and $\mathrm{BC}$ ratio (3.32) similarly, Deshbhratara et al., (2010) found significant increase in grain yield (14.81 q $\left.\mathrm{ha}^{-1}\right)$ and straw yield (41.26 q ha $\left.\mathrm{ha}^{-1}\right)$ of pigeonpea after $20 \mathrm{~kg} \mathrm{~S} h a^{-1}$ and $50 \mathrm{~kg} \mathrm{P}_{2} \mathrm{O}_{5}$ $\mathrm{ha}^{-1}$ treatment with common dose of nitrogen $\left(30 \mathrm{~kg} \mathrm{ha}^{-1}\right)$. The increase in grain and straw yield was 102.77 and 52.87 per cent as compared to higher levels over control. Maximum number of pods per plant, number of grains per pod and test weight with application of $20 \mathrm{~kg} \mathrm{~S}^{-1}$ and $50 \mathrm{~kg} \mathrm{P}_{2} \mathrm{O}_{5}$ $\mathrm{ha}^{-1}$ was also observed when compared to control.

Application of $100 \%$ RDF produced significantly higher seed yield( $\left.998.79 \mathrm{~kg} \mathrm{ha}^{-1}\right)$, plant height, number of branches per plant, dry matter accumulation, number of pods per plantand test weight. The increase in seed yield under application of $100 \%$ RDF was to the tune of 27.63 per cent over $75 \%$ RDF. Significantly higher seedyield $\left(964.27 \mathrm{~kg} \mathrm{ha}^{-1}\right)$ was recorded with the application of FYM @ $5 \mathrm{t} \mathrm{ha}^{-1}$ which was 18.01 per cent higher over control Shete et al., (2010). Sutaria et al., (2010)Maximum grain yield $\left(668 \mathrm{~kg} \mathrm{ha}^{-1}\right)$ of greengram was recorded with $50 \% \mathrm{RDF}+1 \mathrm{t}$ $\mathrm{ha}^{-1}$ vermicompost, while, with application of $100 \%$ RDF the yield of blackgram was 1029 $\mathrm{kg} \mathrm{ha}^{-1}$ and cowpea $825 \mathrm{~kg} \mathrm{ha}^{-1}$. Thanki and Solanki (2010) concluded that irrigating the crop at 0.9 IW/CPE ratio resulted in significantly higher seed $\left(1,429 \mathrm{kgha}^{-1}\right)$ and straw $\left(3,921 \mathrm{kgha}^{-1}\right)$ yields and application of $100 \%$ RDF (20-40-0 NPK kg ha-1) recorded significantly higher seed $\left(1,402 \mathrm{kgha}^{-1}\right)$ and straw $\left(3,809 \mathrm{~kg} \mathrm{ha}^{-1}\right)$ yields. Subba Rami Reddy et al., (2011) revealed that performance of pigeonpea was better with combined application of inorganic fertilizers and biofertilizers. Application of 50\% RDF through inorganic fertilizer + Rhizobium @ $200 \mathrm{gkg}^{-1}$ seed at the time of sowing recorded significantly higher number of branches (16.3 plant $\left.^{-1}\right)$ and pods (151.3 plant $^{-1}$ ) followed by RDF + FYM + Rhizobium (14 and 142.6plant ${ }^{-1}$ ) and 50\% RDF + Rhizobium + PSB (14 \& 133.8plant $\left.{ }^{-1}\right)$ respectively.

Arjun Sharma et al., (2012) concluded that pigeonpea + greengram intercropping systems recorded significantly higher pigeonpea seed yield (14.43 qha $\left.^{-1}\right)$, pigeonpea equivalent yield $\left(17.13 \mathrm{q} \mathrm{ha}^{-1}\right)$, gross returns (Rs.40,983ha-1), net returns (Rs. 32,499ha ${ }^{-1}$ ) and $\mathrm{BC}$ ratio (3.81) over pigeonpea + pearl millet intercropping system (13.23 $\mathrm{qha}^{-1}$, 14.78 qha $^{-1}$, Rs. $35,483 \mathrm{ha}^{-1}$, Rs. 27,230ha ${ }^{-1}$ and 3.29, respectively). The seed yield of pigeonpea, pearl millet and greengram increased significantly due to combined application of FYM, RDF and biofertilizers as compared to control. 


\section{Micronutrients}

The yield potential of pigeon pea is at to be trapped at irrigation and rainfed condition is mainly attributed to their cultivation on poor soils with inadequate and imbalanced nutrient application without the application of organic manures and micronutrients like boron, zinc and iron. Since the poor soils are low in organic matter content, combined application of organic manures in addition with micronutrients plays a vital role in improving soil physical condition, provide vital plant nutrients and maintains long term productivity of the soil. Several investigations were carried out in India to study the effect of different micronutrients on pigeon pea productivity (Table 1).

Boron nutrition of soil and crops has assumed greater importance with the introduction of high yielding crop varieties under intensive cultivation with high use of chemical fertilizers. The yield and quality of crops have a significant bearing in relation to availability and transformation of Boron. The literature pertaining to the effect of Boron on yield and quality of crops are reviewed and presented below.

Asokan and Raj (1974) studied the response of groundnut grown in pot culture to various forms and levels of $\mathrm{B}$ and reported that application of $15 \mathrm{~kg}$ of boric acid or borax $\mathrm{ha}^{-1}$ increased the yield of crop appreciably and it also improved the formation of pods in plants.

Kalyani et al., (1993) observed that B applied as boric acid increased the plant height, relative growth rate, net assimilation rate and leaf area index in pigeonpea. The magnitude of yield response to soil applied $\mathrm{B}$ ranged from 0.10 to $11.9 \mathrm{q} \mathrm{ha}^{-1}$ in cereals, 1.2 to 15.5 $\mathrm{q} \mathrm{ha}^{-1}$ in pulses, 0.14 to $5.0 \mathrm{q} \mathrm{ha}^{-1}$ in oil seeds, 28.3 to $79.5 \mathrm{q} \mathrm{ha}^{-1}$ in onion and $105 \mathrm{q} \mathrm{ha}^{-1}$ in sugarcane (Sakal et al., 1996).
Irrespective of the soils, increasing levels of B increased the filling and shelling percentage of groundnut which might be due to the role of B in sugar transport and utilization by developing pollen and embryos, fruit and seeds and its unique role in cell wall structure and function (Slavko Perica et al., 2001). Salam et al., (2004) reported that B increased the plant growth, leaf area index and root length and root nodules of bean.

Tekale et al., (2009) concluded that application of IAA irrespective of concentrations in combination with boron and zinc at flowering and podding stages in pigeonpea was found most effective in prevention of flower and premature abscission and acceleration of assimilate translocation as well, while foliar application of the same at flowering or pod initiation, individually, seems to alter the growth parameters or yield contributing traits partially. Malla Reddy et $a l$. , (2010) studied the effect of micronutrients on growth and yield of pigeonpea and revealed that application of $\mathrm{N}, \mathrm{P}, \mathrm{K}$ and $\mathrm{S}$ at 20, 50, 20 and $20 \mathrm{~kg} \mathrm{ha}^{-1}$ along with sodium molybdate at $3.0 \mathrm{~kg} \mathrm{ha}^{-1}$ to soil recorded significantly higher yield $\left(2.3 \mathrm{t} \mathrm{ha}^{-1}\right)$ and was on par with all other treatments, except application of recommended dose of $\mathrm{N}, \mathrm{P}, \mathrm{K}$ and $\mathrm{S}$ (RDF) at 20, 50, 20 and $20 \mathrm{~kg} \mathrm{ha}^{-1}$ respectively $\left(1.9 \mathrm{t} \mathrm{ha}^{-1}\right)$. Similar trend was observed in case of pods per plant. In addition to RDF, either seed treatment or soil application of micronutrients significantly increased the yield compared to RDF only.

In India zinc deficiency is wide spread. Zinc is now being regarded as the third most important limiting nutrient element in crop production after $\mathrm{N}$ and $\mathrm{P}$ (Gupta, 1995). In plants, zinc plays an important role in chlorophyll formation, synthesis of indole acetic acid, carbohydrate and $\mathrm{N}$ metabolism and also synthesis of proteins which lead to 
high yield and yield components. Devarajan et al., 1980 reported application of $\mathrm{ZnSO}_{4} @$ $12.5 \mathrm{~kg} \mathrm{ha}^{-1}$ increased the grain yield of greengram significantly. Further, significant increase in straw yield of blackgram was obtained by application of $\mathrm{ZnSO}_{4} @ 12.5 \mathrm{~kg}$ $\mathrm{ha}^{-1}$ while grain yield did not differ significantly. Further application of $\mathrm{ZnSO}_{4}$ had a greater impact in increasing the uptake of NPK by cowpea. It also improved the haulm yield of the crop (Krishnasamy et al., 1985).While, Ahmed et al., (1986) revealed that the growth and yield of mungbean was higher with application of zinc at $5 \mathrm{~kg} \mathrm{ha}^{-1}$ and application of zinc more than $5 \mathrm{~kg} \mathrm{ha}^{-1}$ had no significant effect on growth, yield and quality of mungbean. Similarly Takkar and Nayyar (1986) observed a yield gain of 320 $\mathrm{kg} \mathrm{ha}^{-1}$ in chickpea with the application of zinc sulphate @ $25 \mathrm{~kg} \mathrm{ha}^{-1}$. While, Devarajan et al., (1987) reported that application of zinc in the form of zinc sulphate @ $25 \mathrm{~kg}$ per ha significantly increased the grain yield of greengram cv. CO-3.

Jha and Chandel (1987) reported that the foliar application of zinc @ 4 ppm as $\mathrm{ZnSO}_{4}$ produced significantly higher dry matter per plant during kharif season in soybean. In general, zinc rates beyond $4 \mathrm{ppm}$ resulted in reduction of dry matter. Foliar application of zinc @ 4 ppm resulted in 40 per cent higher dry matter production per plant over control and such response was expected only in soils deficit in zinc. Prasad and Ram (1988) reported that combined soil application of zinc and copper@2.5 kg ha ${ }^{-1}$ recorded significantly higher plant height $(24.13 \mathrm{~cm})$ and dry matter accumulation $\left(2.4 \mathrm{~g} \mathrm{plant}^{-1}\right)$ in greengram compared to control. Puste and Jana (1988) reported positive and linear increase in the yield of pigeonpea due to application of zinc sulphate from 0 to $20 \mathrm{~kg}$ per ha and concluded that application of $25 \mathrm{~kg}$ zinc sulphate per ha resulted in economically higher returns.Singh et al., (1988) in their study conducted on zinc deficient alluvial soils of University Research Farm at Kanpur during kharif season reported significant increase in the grain $\left(15.80 \mathrm{q} \mathrm{ha}^{-1}\right)$ and straw $\left(3.62 \mathrm{q} \mathrm{ha}^{-1}\right)$ yield of pigeonpea due to application of zinc sulphate @ $20 \mathrm{~kg}$ per ha over control.

Addition of zinc sulphate up to $15 \mathrm{~kg}$ per hectare favourably increased zinc, iron and magnesium content in mung grain. However, further increment in zinc sulphate did not affect the composition and quality of mung grain. Increase in protein and soluble carbohydrate content may be attributed to the involvement of zinc in protein and carbohydrate synthesis (Malewar et al., 1990). Zinc at $5 \mathrm{ppm}$ stimulated all the growth parameters of chickpea. Increasing the level of zinc up to $10 \mathrm{ppm}$ had a depressing effect on all growth parameters except the root dry weight. Zinc is required for the production of indole acetic acid which is important for nodulation in legumes (Saxena and Rewari, 1990). Hugar and Kurdikeri (2000) concluded that seed quality parameters like oil content $(20.10 \%)$, protein content $(39.70 \%)$ and germination percentage $(89.60$ $\%)$ were significantly higher at higher levels of zinc sulphate application compared to lower levels of zinc (19.08, 37.78 and 88.09 $\%$, respectively) in soybean. Umesh Singh and Yadav (2000) reported that application of zinc sulphate@5 kg per ha enhanced the seed yield of greengram significantly over control. Misra (2001) opined that zinc application to alkaline soils resulted in significant improvement in grain yield of pea by inducing crop tolerance to alkalinity.

Zinc helped in narrowing down $\mathrm{Na} / \mathrm{K}$ and $\mathrm{Na} / \mathrm{Ca}+\mathrm{Mg}$ ratios in tissues. Seed treatment of chickpea with zinc sulphate at $20 \mathrm{mg} \mathrm{Zn}$ per $\mathrm{kg}$ seeds increased nodule dry weight, leghaemoglobin content, nitrogenase activity, indole acetic acid content and nitrogen 
content in nodules by inducing tolerance to alkalinity on alkaline soils (Misra et al., 2002).

Swarna Ramesh (2002) reported that foliar application of $\mathrm{ZnSO}_{4} @ 0.5$ per cent significantly increased the number of seeds per plant, number of pods per plant, pod weight and pod length in mothbean. Sangwan and Raj (2004) suggested application of $5 \mathrm{~kg}$ $\mathrm{ZnSO}_{4} \mathrm{ha}^{-1}$ in the light textured soils to meet the $\mathrm{Zn}$ requirement of chickpea under dryland conditions. Application of $\mathrm{ZnSO}_{4}$ at $9 \mathrm{~kg}$ per ha resulted in significant response over control in terms of plant height, number of branches per plant, number of pods per plant, 1000 grain weight and grain as well as biological yield of chickpea. Also the highest grain yield was obtained with $9 \mathrm{~kg} \mathrm{ZnSO}_{4}$ ha 1. Application of $9 \mathrm{~kg} \mathrm{ZnSO}_{4} \mathrm{ha}^{-1}$ increased the harvest index from 36.6 to 39.8 per cent indicating better utilization of photosynthates towards sink. Highest benefit cost ratio was obtained with $9 \mathrm{~kg} \mathrm{Zn} \mathrm{ha-1} \mathrm{(Singh} \mathrm{et} \mathrm{al.,}$ 2005).

Application of $6 \mathrm{~kg}$ zinc sulphate per ha produced significantly higher plant height, dry weight, nodule number and dry weight, pod length, pod number and weight, seeds per pod, 100- seed weight, grain and straw yields, nutrient uptake and protein harvest of frenchbean over control, zinc sulphate @ $3 \mathrm{~kg}$ $\mathrm{ha}^{-1}$ and other micronutrients like boron. Also application of $6 \mathrm{~kg}$ zinc sulphate $\mathrm{ha}^{-1}$ recorded highest benefit cost ratio of 2.54 (Singh et al., 2006).Zinc stress (both deficiency and excess) caused reduction in biomass and economic yield of frenchbean. The concentrations of reducing sugars, starch, soluble protein and specific activity of carbonic anhydrase decreased and stimulation in specific activities of acid phosphatase and ribonuclease in leaves and pods of frenchbean were observed under zinc stress. The concentration of zinc in dry matter increased with an increase in zinc supply (Chatterjee,
2008). Field experiment conducted by Narayana et al., (2008) revealed that application of $\mathrm{ZnSO}_{4}$ @ one per cent as foliar spray at 25 DAS recorded significantly higher grain yield $\left(1,166 \mathrm{~kg} \mathrm{ha}^{-1}\right)$ of cowpea compared to soil application. Shanti et al., (2008) reported that, increasing levels of $\mathrm{ZnSO}_{4}$ increased the seed yield and haulm yield of blackgram. The highest seed and haulm yields were recorded when $\mathrm{ZnSO}_{4}$ was applied at $25 \mathrm{~kg} \mathrm{ha}^{-1}$.

Experiment conducted by Khorgamy and Farnia (2009) revealed that zinc had a significant effect on number of pods per plant, number of seeds per pod and harvest index of chickpea. According to Sharma et al., (2010) in kharif pigeonpea, application of $\mathrm{ZnSO}_{4}$ @ $15 \mathrm{~kg} \mathrm{ha}^{-1}+\mathrm{RDF}$ recorded significantly higher plant height $(196.1 \mathrm{~cm})$, number of primary branches per plant (10.1), number of pods per plant (128.2), number of seeds per pod (3.49), 100 seed weight $(9.81 \mathrm{~g})$ and protein content $(20.71 \%)$ compared to the application of RDF alone.

Also higher gross income (Rs. 22,655 ha-1), net income (Rs.14,006ha ${ }^{-1}$ ) and $\mathrm{BC}$ ratio (2.16) was obtained due to $\mathrm{RDF}+\mathrm{ZnSO}_{4}$ @ $15 \mathrm{~kg} \mathrm{ha}^{-1}$.Sivasankar et al., (2012) conducted experiment on phytoremediating capability and nutrient status of four plant species under zinc stress and concluded that the 50-100 mg $\mathrm{kg}^{-1}$ level of zinc in the soil was beneficial for the growth of chilli, marigold, mustard and pigeonpea plants. The level of zinc in the soil above $150 \mathrm{mg} \mathrm{kg}^{-1}$ proved to be toxic. The results indicated that the $50-100 \mathrm{mg} \mathrm{kg}^{-1}$ zinc level can be applied for increasing the growth and yield of chilli, marigold, mustard and pigeonpea plants.

Srikanth Babu et al., (2012) studied the effect oforganic manures and graded levels of zinc sulphate onyield and yield components and economics of pigeonpea cultivation and 
concluded that the grain yield recorded with the application of poultry manure was significantly superior $\left(1,342 \mathrm{~kg} \mathrm{ha}^{-1}\right)$ over the grain yield recorded with the application of farmyard manure $\left(1,160 \mathrm{~kg} \mathrm{ha}^{-1}\right)$ and control $\left(1,038 \mathrm{~kg} \mathrm{ha}^{-1}\right)$ and was on par with the yield obtained in treatment receiving vermicompost $\left(1,299 \mathrm{~kg} \mathrm{ha}^{-1}\right)$ and significantly higher seed yield $\left(1,324 \mathrm{~kg} \mathrm{ha}^{-1}\right)$ was obtained with $\mathrm{ZnSO}_{4}$ @ $20 \mathrm{~kg} \mathrm{ha}^{-1}$ when compared to no zinc sulphate $\left(1,048 \mathrm{~kg} \mathrm{ha}^{-1}\right)$ and $\mathrm{ZnSO}_{4} @ 10$ $\mathrm{kg} \mathrm{ha}^{-1}\left(1,171 \mathrm{~kg} \mathrm{ha}^{-1}\right)$ while it was on par with $\mathrm{ZnSO}_{4} @ 15 \mathrm{~kg} \mathrm{ha}^{-1}\left(1,296 \mathrm{~kg} \mathrm{ha}^{-1}\right)$.

Iron deficiency or its chlorosis is a serious constraint to crop production in many upland alkaline, calcareous and coarse textured soils low in organic matter. Zeidan et al., (2006) conducted experiment on yield and quality of lentil as affected by micronutrient deficiencies in sandy soils and concluded that application of micronutrients successfully prevented occurrence of chlorosis and increased plant height, number of branches and pods plant ${ }^{-1}$, seed yieldplant ${ }^{-1}, 1000$ seed weight, seed yield $\mathrm{ha}^{-1}$ and macro as well as micronutrients uptake as compared to control and NPK treatments. Palsaniya and Ahlawat (2007) conducted the experiment on crop productivity, quality and nutrient uptake of pigeonpea (Cajanus cajan L.) - wheat (Triticum aestivum) cropping system as influenced by sulphur management and concluded that application of $\mathrm{S}$ to pigeonpea significantly enhanced the mean grain yield (pigeonpea $1.63 \mathrm{t} \mathrm{ha}^{-1}$, wheat $4.23 \mathrm{tha}^{-1}$ ) and stalk yield (5.56 tha $\left.{ }^{-1}\right)$ and, straw yield (5.93 tha $\left.{ }^{-1}\right)$, protein content and total $\mathrm{N}$ and $\mathrm{S}$ uptake of pigeonpea and succeeding wheat over the control. Mohammad Islamet al., (2009) studied the effect of integrated application of phosphorus and sulphur onyield and micronutrient uptake by Chickpea (Cicer arietinum) and concluded that application of $\mathrm{P}$ and $\mathrm{S}$ resulted in significant increase in grain yield ranging from 22 to $35 \%$ and 10 to $16 \%$ over control, respectively. Ali Akbar Moosaviand Abdolmajid Ronaghi (2012) revealed that soil or foliar application of $\mathrm{Fe}$ or Mn did not influence soybean root or shoot dry matter yield (SDMY). Both soil and foliar applications of $\mathrm{Fe}$ significantly increased shoot Fe concentration and uptake.

Table.1 The effect of different micronutrients on pigeon pea productivity

\begin{tabular}{ll}
\hline Micronutrients & Reference \\
\hline Boron application & Asokan and Raj (1974), Kalyani et al., (1993),Sakal et \\
& al.,1996, Slavko Perica et al., 2001, Tekale et al., (2009) and \\
& Malla Reddy et al., (2010) \\
\hline Zinc sulphate application & Devarajan et al., 1980, Anon., 1981, Ahmed et al., (1986), \\
& Takkar and Nayyar (1986), Devarajan et al., (1987), Jha and \\
& Chandel (1987), Prasad and Ram (1988), Puste and Jana \\
& (1988), Singh et al., (1988), Malewar et al., 1990, Saxena \\
& and Rewari, 1990, Sunanda Sarkar and Aery (1990), Kasturi \\
& Krishna and Ahlawat (1999), Umesh Singh and Yadav \\
& (2000), Misra (2001), Swarna Ramesh (2002), Sangwan and \\
& Raj (2004), Shanti et al., (2008), Sivasankar et al., (2012) \\
& and Srikanth Babu et al., (2012) \\
\hline Zeidan et al., (2006), Palsaniya and Ahlawat (2007), \\
Mohammad Islamet al., (2009), Ali Akbar Moosaviand \\
Abdolmajid Ronaghi (2012) and Alirezaladan Moghadamet \\
al., (2012) \\
\hline
\end{tabular}


Soil application of 4 and $8 \mathrm{mg} \mathrm{Fe} \mathrm{kg}^{-1}$ significantly increased shoot Fe concentration or uptake by about 1.4 and 1.5 fold; however, foliar application of 1 and $2 \quad \% \quad \mathrm{FeSO}_{4}$ increased these parameters by more than 2.5 and 3.1 fold in comparison to that of control.

Alirezaladan Moghadam et al., (2012) revealed that nano fertilizer solution injection was performed in early morning when plant had 8-13 leaves. Results showed that wet weight and maximum leaf area index was influenced by concentration of iron chelate nano fertilizer and dry weight was influenced by both type of spinach and concentration of nano fertilizer. Using $4 \mathrm{~kg} \mathrm{ha}^{-1}$ nano fertilizer caused 58 and 47 per cent increase inwet weight and maximum leaf surface index, respectively comparing to use of no fertilizer.

\section{Macro nutrients applied through water as liquid fertilizer}

Combined application of water and nutrients proved to be more appropriate, efficient and effective in crop production with better response than either band or broadcasting method. Ravindranath et al., (1985) studied the effect of foliar application of potassium on the growth pattern and yield components of three cultivars of pigeonpea [Cajanus cajan (L.) Millsp.] and concluded that potassium increased plant height and dry matter accumulation in all the three cultivars. Days to maturity was not much affected. Potassium increased yield in all the cultivars but at different levels, flower drop was reduced conspicuously. However, among the cultivars studied, cv.PDM-1 showed better response than the others. Further, Foliar nutrition is recognized as an important method of fertilizer application since foliar nutrient usually penetrate the leaf cuticle or stomata and enter the cells facilitating easy and rapid utilization of nutrients (Tisdale et al., 1995).Shahid Umar et al., (1999) conducted experiment on the effect of foliar fertilization of potassium on yield, quality and nutrient uptake of groundnut and revealed that pod yield were significantly higher when basal and foliar application were combined. Senthil Valavan and Kumaresan (2006) conducted experiment on relative efficiency of controlled release and water soluble fertilizers on the yield and quality of chilli (Capsicum annuum L.) and revealed that the soil application of $50 \%$ NPK + water soluble fertilizers (foliar spray at 1 or $2 \mathrm{~g} \mathrm{~L}^{-1}$ ) foliar spray was found to be the best combination which had enhanced the green chilli yield (8.86 and $8.94 \mathrm{t} \mathrm{ha}^{-1}$, respectively) and quality viz., Capsaicin (4.16 and $4.19 \mathrm{mg} 100 \mathrm{~g}^{-1}$ ), respectively as against the NPK control. Bera et al., (2008) studied the effect of foliar application of brassinolide and salicylic acid on NPK content in leaf and nutrient values of seed in greengram (Vigna radiata $\mathrm{L}$. wilezek) and revealed that foliar application of these plant growth regulators once at pre flowering (30 DAS) and second time at flowering stage (40 DAS) significantly increased NPK content in leaves of greengram up to 50 DAS followed by gradual decline till harvest of crop. Nutritive value of seed particularly, sugar, starch, protein, methionine and ascorbic acid content were found to be influenced by application of these bioregulators.

Similarly, Selvi et al., (2009) conducted experiment on agronomic management for pigeonpea under drought conditions and concluded that application of recommended dose of fertilizer (RDF) + cultural mulch two times recorded the maximum yield of 568 and $557 \mathrm{kgha}^{-1}$ during 2004 and 2005, respectively. During kharif 2005, rainfall coincided with flowering and hence $2 \%$ urea spray at flowering was able to give comparable yield as that of RDF + cultural mulch two times. Premsekhar and Rajashree (2009) conducted experiment on the 
performance of hybrid tomato as influenced by foliar feeding of water soluble fertilizers and concluded that among the different grades of water soluble fertilizers, foliar application of 5 sprays of NPK (19:19:19) recorded the tallest plants, highest fruit weight, fruits plant ${ }^{1}$, fruit yield and BC ratio. The same treatment also recorded better quality fruits with 4.460 Brix. Hamideh Shirvani Sarakhsi et al., (2010) studied the effect of nitrogen foliar application in different concentration and growth stage of corn (Hybrid 704) and concluded that plant height, leaf dry weight, yield, fertilizer use efficiency, rows in ear, seeds in row, seeds in ear and shoot dry weight affected significantly at $1 \%$ level of probabilities. Afifi and Khattab (2011) conducted experiment on response to foliar application of urea and zinc on yield and chemical content of maize plant and concluded that application of urea and zinc had significant and positive effect in both seasons and the highest values were obtained by 100 per cent application of nitrogen combined with urea foliar adding treatment.

Gupta et al., (2011) conducted experiment on the effect of bio fertilizers and foliar spray of urea on symbiotic traits, nitrogen uptake and productivity of chickpea and revealed that application of $20 \mathrm{~kg} \mathrm{~N} \mathrm{ha}^{-1}+$ Rhizobium + PSB + PGPR + $2 \%$ urea spray at flowering and 10 days thereafter gave maximum nodule number and nodule dry weight and ultimately gave higher yield $\left(1224 \mathrm{~kg} \mathrm{ha}^{-1}\right)$.

Kuttimani and Velayutham (2011) conducted experiment on foliar application of nutrients and growth regulators on yield and economics of greengram and revealed that foliar application of $2 \%$ DAP +100 ppm salicylic acid $+0.05 \%$ sodium molybdate twice at vegetative and flowering stages of crop growth recorded higher yield parameters (number of seeds per pod and 100 seed weight) and economics. Mondal et al., (2011) studied the effect of foliar application of nitrogen and micronutrients on growth and yield in mungbean and concluded that foliar application of $\mathrm{N}$ or $\mathrm{N}$ with micronutrients increased leaf area, specific leaf weight, chlorophyll content, total dry mass, flower number and reproductive efficiency, yield attributes and yield over the control. Venkatesh and Basu (2011) studied the effect of foliar application of urea on growth, yield and quality of chickpea under rainfed conditions and concluded that foliar application of urea apart from the basal application of RDF increased branching in chickpea by $8-23 \%$ over no spray or water spray. The highest grain yield and yield attributes were recorded with $2 \%$ urea spray at 75 days after sowing (DAS). Jagathjyothi $e t$ al., (2012) revealed that combined application of organic and inorganic sources with foliar spray had enhanced effect on growth and yield of rice crop over application of chemical fertilizer or organic sources alone. Among the nutrient management treatments, the plant height, dry matter production, number of tillers, yield attributes and yield of grain $\left(5631 \mathrm{~kg} \mathrm{ha}^{-1}\right)$ and straw $\left(7647 \mathrm{~kg} \mathrm{ha}^{-1}\right)$ were highest with recommended integrated nutrient management (INM) practice $+2 \%$ urea phosphate spray at panicle initiation and 10 days later. Mondal et al., (2012) studied the effect of foliar application of urea on physiological characters and yield of soybean and revealed that foliar application of urea at $1.5 \%$ three times at reproductive stages may be used for getting increase seed yield in soybean (3.19 t ha ${ }^{-1}$ ). Patil et al., (2012) studied the effect of organics on growth and yield of chickpea (Cicer arietinum L.) in vertisols and concluded that application of enriched compost $1 / 3+$ vermicompost $1 / 3+$ glyricidia leaf manure $1 / 3$ equivalent to 100 $\%$ RDN and foliar spray of panchagavya @ 3 $\%$ at flower initiation and 15 days after flowering recorded significantly higher grain yield $\left(2400 \mathrm{~kg} \mathrm{ha}^{-1}\right)$, haulm yield (3423 $\mathrm{kg} \mathrm{ha}^{-}$ 
$\left.{ }^{1}\right)$, number of pods per plant (66.38) and 100 seed weight $(20.91 \mathrm{~g})$ respectively. Razieh khalilzadeh et al., (2012) studied the effect of foliar application of bio organic fertilizers and urea on yield and yield components of mungbean and revealed that the highest $(60.58 \mathrm{~g})$ and lowest $(53.40 \mathrm{~g}) 1000$ seed weight was observed in foliar application of amino acid and urea treatments respectively. Plants that sprayed with Mas Raiz had the highest seed yield $\left(3810.80 \mathrm{~kg} \mathrm{ha}^{-1}\right)$ and maximum pods per plant were obtained in plants that were treated with extract of cattle manure treatment (41.33) which was highly significant over other treatments. Saravanan et al., (2012) reviewed that foliar application of polyfeed $(1.5 \%)+$ multi $\mathrm{K}(1.5 \%)$ recorded significantly higher yield and better fibre quality such as ginning percentage, lint index, staple length, micronaire value, uniformity ratio, seed index, elongation percentage and tenacity at flowering and boll formation stages. Foliar nutrients significantly altered ginning percentage and lint index in Btcotton.Venkatesh et al., (2012) conducted experiment on effect of foliar application of nitrogenous fertilizers for improved productivity of chickpea under rainfed conditions and revealed that the highest pods per plant (45.3) were recorded in $2 \%$ urea spray at 75 DAS which was 23.7 and $21.3 \%$ higher than control and water spray respectively. The highest seed yield of 2437 $\mathrm{kg} \mathrm{ha}^{-1}$ was recorded with $2 \%$ urea spray at 75 DAS followed by $2 \%$ DAP spray at 75 DAS (2389 kg ha $\left.{ }^{-1}\right)$.

Yadav and Choudhary (2012) studied the effect of fertility levels and foliar nutrition on profitability, nutrient content and uptake by cowpea (Vigna unguiculata L. Walp) and concluded that foliar spray of $2 \%$ DAP, $2 \%$ urea and $2 \% \mathrm{KCl}$ resulted in higher seed yield, net returns, protein content, nitrogen, phosphorus and potassium content in seed and straw and total uptake of $\mathrm{N}, \mathrm{P}$ and $\mathrm{K}$ over water sprayed treatment. One of the most important factors influencing crop productivity is soil fertility. The yields can be maximized only when the soil has capacity to supply sufficient nutrients in balanced proportion, which require optimum fertilizer application that is soil application of RDF along with micronutrients. Foliar application is one of the most efficient ways of supplying essential nutrients to the crop at appropriate stage. Through foliar nutrition of macronutrients, the nutrients are taken into the foliage and distributed to all parts of the plant within a short period of time to get needy effect. It is also effective in correcting the mid-season discrepancies in the crop growth which may be due to either intensive growth or inappropriate supply of nutrients from the soil under abiotic stress conditions. Liquid fertilizers enable the plant to absorb the required nutrients from the solution through their leaf surface and meet the demand of nutrients at the later stage and provide nutrients which are required for crop growth and development from primary stage of development to maturity. Hence balanced fertilization with micronutrients and foliar spray of liquid fertilizers is the sustained nutrient management practice to improve the productivity in pigeonpea.

\section{References}

Afifi, M. H. and Khattab, E. A., 2011, Response of yield and chemical content for foliar application of urea and zinc on some varieties of maize plant. Crop Sci.,1(1):7887.

Ahmed, I. U., Shafiqur Rahman, Nadira Begum and Islam, M. S., 1986, Effect of phosphorus and zinc application on the growth, yield and $\mathrm{P}, \mathrm{Zn}$ and protein content in mungbean. J. Indian Soc. SoilSci., 34: 305- 308.

Ajay Kumar and Rana, K. S., 2007, Performance of pigeonpea (Cajanus cajan L.) + greengram (Phaseolus radiatus) 
intercropping systems as influenced by moisture conservation practice and fertility levels under rainfed conditions. Indian $J$. Agron.,52 (1):31-35.

Ali Akbar Moosavi and Abdolmajid Ronaghi, 2012, Influence of foliar and soil application of iron and manganese on soybean dry matter yield and ironmanganeserelationship in a calcareous soil. Australian J. Crop Sci., 5 (12): 1550-1556.

Alirezaladan Moghadam, Hesam Vattani, Nasim Baghaci and Narges Keshavarz, 2012, Effect of different levels of fertilizer nano-iron chelates on growth and yield characterstics of two varieties of Spinach (Spinacia oleracea L.): Varamin 88 and viroflay. Res. J. Applied Sci. Engineering and Technology., 4(12):4813-4818.

Arjun Sharma, Pandit S. Rathod and Mohan Chavan, 2010a, Integrated nutrient management in pigeonpea (Cajanus cajan L.) based intercropping systems under rainfed conditions. Karnataka J. Agric. Sci., 23(4):584-589.

Arjun Sharma, Pandit S. Rathod and Mohan Chavan, 2010b, Response of pigeonpea (Cajanus cajan L.) to drought management practices under rainfed conditions.Karnataka J. Agric. Sci., 23(5):693-700.

Arjun Sharma, Pandit S. Rathod, Dharmaraj, P. S. and Mohan Chavan, 2012, Response of pigeonpea (Cajanus cajan L.) to biofertilizers in pigeonpea based intercropping systems under rainfed conditions. Karnataka J. Agric. Sci.,25 (3):322-325.

Asokan, S. and Raj, D., 1974, Boron nutrition of crops in relation to yield and quality- A Review. Madras Agric. J.,61(8) : 467-468.

Babhulkar, P. S., Wandile, R. M., Badole, W. P. and Balpande S. S., 2000, Residual effect of long term application of FYM and fertilizers on soil properties (vertisols) and yield of soybean. J. Indian Soc. SoilSci., 48 (1): 89- 92.

Bera, A. K., Maity, U. and Mazumdar, D., 2008, Effect of foliar application of brassinolide and salicylic acid on NPK content in leaf and nutrient values of seed in greengram (Vigna radiata $\mathrm{L}$. wilezek). Legume Res.,31(3):169-173.

Bhattarai, R. K., Singh, L. N. and Singh, R. K. K., 2003, Effect of integrated nutrient management on yield attributes and economics of pea (Pisum sativum). Indian J. Agric. Sci., 74(4): 219- 220.

Chatterjee, J., 2008, Zinc stress disturbed the physiology of frenchbean. Indian J. Plant Physiol., 13 (3): 320- 323.

Deshbhratara, P. B., Singh, P.K., Jambhulkar, A.P. and Ramteke, D.S., 2010, Effect of sulphur and phosphorus on yield, quality andnutrient status of pigeonpea (Cajanuscajan). J. Env. Biol., 31 (6): 933937.

Devarajan, R., Moosa Sheriff, M., Ramanathan, G. and Selvakumari, G., 1980, Effect of phosphorus and zinc fertilization on yield, content and its uptake by pulse crops Indian J. Agric. Res., 14 (1): 47- 52.

Devarajan, R., Savithri, P., Ramaswami, P. P. and Manickam, T. S., 1987, Zinc nutrition of greengram. Madras Agric. J., 74 (5): 518- 521.

Gupta, S. C., Sanjeev Kumar and Khandwe, R., 2011, Effect of bio fertilizers and foliar spray of urea on symbiotic traits, nitrogen uptake and productivity of chickpea. $J$. Food Legumes., 24(2): 155-157.

Hugar, A. B. and Kurdikeri, M. B., 2000, Effect of application methods and levels of zinc and molybdenum on field performance and seed yield in soybean. Karnataka J. Agric. Sci., 13: 439- 441.

Jagathjyothi, M., Muthukrishnan, P. and Mohamed Amanullah, M., 2012, Influence of foliar nutrition on growth and yield of transplanted rice. Madras Agric. J., 99(46): 275-278.

Jha, A. N. and Chandel, A. S., 1987, Response of soybean to zinc application. Indian $J$. Agron., 32: 354- 358.

Kalyani, R. R., Sathya, S., James Pitchai and Indirani, R., 1993, Boron nutrition of crops in relation to yield and quality- A Review. Indian J. Plant Physiol.,36 (4): 223-226.

Kasturi Krishna, S. and Ahlawat, I. P. S., 1999, 
Growth and yield response of pea (Pisum sativum) to moisture stress, $\mathrm{P}, \mathrm{S}$ and $\mathrm{Zn}$ fertilizers. Indian J. Agron., 44: 588- 596.

Khorgamy, A. and Farnia, A., 2009, Effect of phosphorus and zinc fertilization on yield and yield components of chickpea cultivars. African Crop Science Conference Proceedings, 9: 205- 208.

Krishnasamy, R., Manickam, T. S. and Kothandraman, G. K., 1985, Influence of phosphorus and micronutrients on the yield and uptake of NPK in cowpea var. CO 3. Madras Agric. J., 72 (4): 181- 184.

Kuttimani, R. and Velayutham, A., 2011, Foliar application of nutrients and growth regulators on yield and economics of greengram.Madras Agric. J.,98 (4): 141143.

Lokesha, K. R., 2001, Integrated agronomic practices in pigeonpea (Cajanus cajan (L.) Millsp.) for yield maximization. $M$. Sc. (Agri.) Thesis, Univ. Agric. Sci., Dharwad.

Malewar, G. U., Mangnale, M. M. and Vandana Malewar, 1990, Chemical composition and quality of mung genotypes as influenced by zinc fertilization. Legume Res.,13 (2): 5964.

Malla Reddy, M., Padmaja, B., Malathi, S. and Jalapathi Rao, L., 2010, Effect of micronutrients on growth and yield of pigeonpea. J. Environ. Biol.,31 (6): 933937.

Misra, S. K., 2001, Alkalinity and zinc stress effect on performance of different cultivars of pea. Indian J. Pulses Res., 14 (2): 122124.

Misra, S. K., Upadhyay, R. M. and Tiwari, V. N., 2002, Effect of salt and zinc on nodulation, leghaemoglobin and nitrogen content in rabi legumes. Indian J. Pulses Res., 15 (2): 145- 148.

Mohammad Islam, Safdar Ali And Rifat Hayat, 2009, Effect of integrated application of phosphorus and sulphur onyield and micronutrient uptake by Chickpea (Cicer arietinum). Int. J. Agric.Biol.,11: 33-38.

Mondal, M. M. A., Puteh, A. B., Malek, M. A. and Roy, S., 2012, Effect of foliar application of urea on physiological characters and yield of soybean. Legume Res.,35 (3): 202-206.

Mondal, M. M. A., Rahman, M. A., Akter, M. B. and Fakir, M. S. A., 2011, Effect of foliar application of nitrogen and micronutrients on growth and yield in mungbean. Legume Res.,34 (3): 166-171.

Narayana, S. M., Sridhara, S. and Basavaraj Naik, T., 2008, Effect of methods of zinc application on growth and yield of cowpea under rainfed conditions. Res. Crops, 9 (2): 290- 292.

Palsaniya, D. R. and Ahlawat, I. P. S., 2007, Crop productivity, quality and nutrient uptake of pigeonpea (Cajanus cajan L.) wheat (Triticum aestivum) cropping system as influenced by sulphur management. Indian J. Agric. Sci.,7 (10): 660-663.

Patil, A. B. and Padmani, D. R., 2007, Effect of integrated nutrient management on growth and yield of pigeonpea (Cajanus cajan (L.) Millsp.). Int. J. Agric. Sci., 3 (2): 49- 51.

Patil, H. M., and Tumar, S. S. and Wani, A. G., 2008, Effect of integrated nutrient management for pigeonpea + pearl millet intercropping system under dry land conditions. Int. J. Agric. Sci.,4 (1): 335339.

Patil, S. V., Halikatti, S. I., Hiremath, S. M., Babalad, H. B., Sreenivasa, M. N., Hebsur, N. S. and Somanagouda, G., 2012, Effect of organics on growth and yield of chickpea (Cicer arietinum L.) in vertisols. Karnataka J. Agric. Sci., 25 (3): 326-331.

Prasad, J. and Ram, H., 1988, Effect of zinc and copper and Rhizobium inoculation on nodulation and yield of greengram (Vigna radiata). Indian J. Agric. Sci.,58:230- 232.

Premsekhar, M. and Rajashree, V., (2009), Performance of hybrid tomato as influenced by foliar feeding of water solublefertilizers. Am.-Eurasian J. Sustain. Agric., 3 (1): 33-36.

Pujari, B. T., Gundappagol, R. C., Patil, J. R., Suhas Yelshetty and Mannur, D. M., 1998, Conjunctive use of chemical fertilizers, FYM and triacontanol on the performance of pigeonpea. Karnataka J. Agric. Sci., 11 (3): 607- 609. 
Pushpa, M. S., 2007, An economic analysis of demand and supply response of pulses in India. Karnataka J. Agric. Sci., 20 (3): 545550.

Puste, A. M. and Jana, P. K., 1988, Effect of phosphorus and zinc on pigeonpea varieties grown during winter. Indian J. Agron., 33 (4): 399- 404.

Rajkhowa, D. J., Saikia, M. and Rajkhowa, K. M., 2002, Effect of vermicompost with and without fertilizers on greengram. Legume Res., 25 (4): 295- 296.

Ramachandra Reddy, Narayana Reddy, M. A. and Narayana Reddy, Y. T., 1998, Effect of organic and inorganic sources of NPK on growth and yield of Pea (Pisumsativum). Legume Res., 21(1): 57-60.

Ravindranath, N. N. V. S., Satyanarayana, N. V., Prasad, P. and Madhava Rao, K. V., 1985, Foliar application of potassium on the growth and yield components of pigeonpea (Cajanus cajan (L.) Millsp.). Proc. Pl. Sci., 94 (4): 671-676.

Razieh Khalilzadeh, Mehdi Tajbakhsh and Jalal Jalilan, 2012, Effect of foliar application of bio organic fertilizers and urea on yield and yield components of mungbean. Int. J. Agric. Res. Rev., 2 (5): 639-645.

Sakal, R., Sinha, R. B., Singh, A. P. and Bhogal, N. S., 1996, Report of AICRP on micro and secondary nutrients, pollutant element in soils and plants. Ann. Prog. Report., Department of Soil Science, RAU, Pusa, Bihar.

Salam, P. K., Sathya, S., James Pitchai and Indirani, R., 2004, Boron nutrition of crops in relation to yield and quality- A Review. Agric. Rev., 30 (2): 139-144.

Sangwan, P. S. and Raj, M., 2004, Effect of zinc nutrition on yield of chickpea (Cicer arietinum L.) under dryland conditions. Indian J. Dryland Agric. Res. Dev., 19 (1): 1- 3 .

Saravanan, M., Venkitaswamy, R. and Rajendran, K., 2012, Influence of foliar nutrition on seed cotton yield and quality of Bt-cotton. Madras Agric. J., 99(4-6): 332334.

Sarkar, R. K., Shit, D. and Chakraborty, A.,
1997, Effect of levels and sources of phosphorus with and without FYM on pigeonpea (Cajanus cajan L.) under rainfed condition. Indian J. Agron., 42 (1): 120123.

Saxena, A. K. and Rewari, R. B., 1990, Influence of zinc on nodulation and iron uptake by chickpea under saline conditions. J. Indian Soc. SoilSci., 38: 363- 364.

Senthil Valavan, P. and Kumaresan, K. R., 2006, Relative efficiency of controlled release and water soluble fertilizers on the yield and quality of chilli (Capsicum annuum L.). Inter. J. Soil Sci., 1 (3): 264 268.

Shahid Umar, Bansal, S. K., Patricia Imas and Magen, H., 1999, Effect of foliar fertilization of potassium on yield, quality and nutrient uptake of groundnut. J. Plant Nutr., 22 (11): 1785-1795.

Shanti, M., Peda Babu, B., Rajendraprasad, B. and Minhas, B. S., 2008, Effect of zinc on blackgram in rice- blackgram cropping system of coastal saline soils. Legume Res. 21 (2): 79- 86.

Sharma, A., Nakul, H. T., Jelgeri, B. R. and Ashok Surwenshi, 2010, Effect of micronutrients on growth, yield and yield components in pigeonpea (Cajanus cajan (L.) Millsp.). Res. J. Agric. Sci., 1 (2): 142144.

Shete, P. G., Thanki, J. D., Adhav, S. L. and Kushere, Y. M., 2010, Response of rabi greengram (Vigna radiata L) to land configuration and inorganic fertilizer with and without FYM.Crop Res., 39 (1, 2 \& 3): 43-46.

Singh, A. K., Bhagwan Singh and Singh, H. C., 2005, Response of chickpea (Cicer arietinum L.) to fertilizer phosphorus and zinc application under rainfed condition of Eastern Uttar Pradesh. Indian J. Dryland Agric. Res. Dev., 20 (2): 114- 117.

Singh, R., Yashwant Singh, Singh, O. N. and Sharma, S. N., 2006, Effect of nitrogen and micronutrients on growth, yield and uptake by frenchbean. Indian J. Pulses Res., 19 (1): $67-69$.

Singh, T., Tewari, K. N. and Pathak, A. N., 
1988, Yield, zinc uptake and content of nutrients as influenced by zinc application in pigeonpea. Indian Agric., 32: 55- 61.

Sivasankar, R., Kalaikandhan, R. and Vijayarengan, P., 2012, Phytoremediating capability and nutrient status of four plant species under zinc stress. Int. J. Res. Plant. Sci.,2 (1): 8-15.

Srikanth Babu, P. N., Koppalkar, B. G., Nagalikar, V. P. and Pramod Katti, 2012, Yield and yield components and economics of pigeonpea cultivation as influenced by organic manures and graded levels of zinc sulphate. Karnataka J. Agric. Sci.,25 (4): 527-530.

Subba Rami Reddy, A., Sateesh Babu, J., Chandra Sekhar Reddy, M., Mujeeb Khan, Md. and Murali Rao, M., 2011, Effect of integrated nutrient management in pigeonpea (Cajanus cajan L.). Inter. J. Applied Bio. Pharm. Tech.,2 (2): 467-470.

Sunanda Sarkar, A. P. and Aery, N. C., 1990, Effect of zinc on growth of soybean. Indian J. Plant Physiol., 33: 239- 241.

Sutaria, G.S., Akbari, K. N., Vona, V. D., Hirpara, D. S. and Padmani, D. R., 2010, Response of legume crops to enriched compost and vermicompost on vertic ustochrept under rainfed agriculture. Legume Res., 33 (2): 128-130.

Swarna Ramesh, 2002, Effect of plant growth regulators, chemicals and nutrients on morphophysiological, biochemical and yield and yield attributes in mothbean [Vigna aconitifolia (Jacq.) Marchel].M. Sc. (Agri.) Thesis, Univ. Agric. Sci., Dharwad.
Takkar, P. N. and Nayyar, V. K., 1986, Integrated approach to combat micronutrient deficiency. Proceedings of FAI Annual Seminar. PS III/ 2/ 1- 8.

Thanki, J. D. and Solanki, R. K., 2010, Response of rabi pigeonpea (Cajanus cajan (L.) Millsp.) to moisture regimes and fertilizer management with and without FYM under South Gujarat conditions. Crop Res., 39 (1, 2 \& 3): 39- 42.

Tisdale, S.L., Nelson, W.L., Beaton, J.D., and Havlin, J.L., 1995. Soil fertility and fertilizers. Prentice Hall of India Pvt. Ltd., New Delhi, 506-507.

Umesh Singh and Yadav, D. S., 2000, Studies on sulphur and zinc nutrition on greengram in relation to growth attributes, seed protein yield, S and Zn uptake. Legume Res., 20 (3): 224- 226.

Venkatesh, M. S. and Basu, P. S., 2011, Effect of foliar application of urea on growth, yield and quality of chickpea under rainfed conditions. Food Legumes.,24 (2): 110112.

Yadav, L. R. and Choudhary, G. L., 2012, Effect of fertility levels and foliar nutrition on profitability, nutrient content and uptake of cowpea (Vigna unguiculata L. walp). Legume Res., 35 (3): 258-260.

Zeidan, M. S., Hozayn, M. and Abd El-Salam, M. E. E., 2006, Yield and quality of lentil as affected by micronutrient deficiencies in sandy soils. J. Applied Sci. Res., 2(12): 1342-1345.

\section{How to cite this article:}

Vinayak Hosamani, B.M. Chittapur, Venkatesh Hosamani and Rajanand Hiremath. 2017. Sustained Nutrient Management Practice for Pulse Production: A Review. Int.J.Curr.Microbiol.App.Sci. 6(11): 3773-3786. doi: https://doi.org/10.20546/ijcmas.2017.611.442 